\title{
LYRIC PLOT OR THE FORM CONTENT OF THE CROWN OF GUY SABYTOV'S SONNETS
}

\author{
Vasiliy Vanjushev \\ Section of philological studies \\ Udmurt institute of the history of language and literature \\ of Uralian department of Russian Academy of Sciences \\ 4 Lomonosova str., Igevsk, Russian Federetion, 426004 \\ vvanushev@mail.ru
}

\begin{abstract}
On the example of the crown of sonnets “Шунды но жужа но...” (“Sun sets - sun rises”) by Guy S. Sabytov is considered the form and content ratio of lyric composition. There was revealed that the main content of analyzed text is the approval of the idea of eternity, immortality of good deals, kind, talented people. Poet created the double verbal memorial - for the untimely died friend poet and director M. Pokchy-Petrov and for himself. The image of the first of them as an object of representation is created not only by mentioning the concrete features of his biography but also by the "reflected light" of his perception by the other. The image of second of them as an object and subject of representation is drawn on the base of his empathy to the first one. The form of the crown of sonnets favors the successful disclosure of such structure of its content.
\end{abstract}

Keywords: the first crown of sonnets in Udmurt literature, poetics of the art composition, lyric plot, the verbal memorial for himself and his friend-artist.

(C) Vasiliy Vanjushev

\section{Introduction}

Udmurt literature as the writing verbal memorial of the several nations of Ural-Povolzhye and Nothern Caucasus by definition of the philosopher of literature, professor, R. F. Yusufov [1-2] is referred to phenomena of ethnic culture with the late literature genesis. Whereas the world literature already has in it base the thousand years of development, the system of genre diversity of verbal art of the aforesaid interregional community became to form only in XIX century. Through the Russian literature and under its influence there were formed the distinct forms of poem. Sonnet, triolet, rondo, rondel appeared, for example, in Udmurt literature in the oeuvre of diversely talented poet and scientist Kuzebay Guerda (Chaynikov Kuzma Pavlovich) in 1920 years. The sonnet is the most stable form in the further history of Udmurt poetry. The elements of distinct forms of poem that are repeated in the structure and content bearing psychological and philosophical load began to appear also in poetic compositions of the big genre. It was demonstrated, for example in the poem by Michael Petrov "Italmas" (1946), that generated even the term "iltmass strophe" because of singularity of its rhythm-strophe organization; this term is used in Udmurt literary criticism [3]. Possibly it favored the appearance of lyric-philosophical poem - the first crown of sonnets in Urmurt language [4], in which the radio-journalist and poet-songwritter Guy Sabytov practically confessed to the friend, poet and director Michael Pokchy-Petrov untimely gone to another world.

The poem was perceived rapturously [5]. The colleges' success inspired many Udmurt poets. N. A. Atnabaeva in candidate thesis "Sonnet genre in Udmurt" [6] along with consideration of the ways of development of this poetic form analyzed more than ten crowns of sonnets by eight authors and divided it into idea-thematic groups. Then she specially appealed to the experience of the crowns of sonnets - dedications in Udmurt and closely related Komi and Mordovia literatures [7]. The author of publication writes in abstract: "There are considered the general development tendencies of this genre, civic orientation of composition. The organizing center of the crown is the destinies of famous persons of national culture: in Udmurt poetry it is poet Ashalchi Oki and dramatist Michael Pokchy-Petrov, in Komi literature - classic of Komi poetry Ivan Kuratov, in Mordovian - the genial 
sculptor Erzya. There are considered not only the dominating images but also event-sense elements connected with it" [7].

There is in general the work on "inventory" and primary analysis of sonnet creation of Udmurt (and several neighboring) poets. It is undoubtedly needs continuation, first of all, in aspect of internal structures of compositions, of connections between the different elements of its form and content that is necessary for more deep understanding of not only idea-thematic but also theoretic history of national literature.

\section{Aims and tasks of this research}

Well known phrase: form of art composition is its content. Author of these lines wanted to demonstrate on concrete examples how this principle is realized in the crown of G. Sabytov's sonnets that is to demonstrate the very process of materialization of the content sides by its formal data. This aim is ambivalent. From the one side it presupposes the small but important concrete problem on the way of creation of theoretical history of national literature; from the other one it solves the educational-pedagogical problem: directs the teachers of national literature on the searches of internal core mechanisms of materialization of emotional-intellective sides of art texts content.

\section{On the ways of theoretical history of Udmurt poem or destruction of dogmatic claims in literature education}

For a long time in Soviet literary education was accepted that plot is typical only for epic and dramatic genres of literature. Few years ago, when the author of this article worked at the faculty of Udmurt philology of UdSU he was warn: "don't talk students about "lyric plot", they will repeat it". Surely it was impossible to accept this absurd claim. Even in 1920-th the famous theoretic of literature Boris Viktorovich Tomashevsky (1890-1957) introduced the notion "lyric deploy" which was further identified by the words "lyric plot" in the works of Y. N. Tynyanov, D. O. Lihachev, B. E. Egorov, B. O. Korman and others.

In the early 1930-th B. O. Tomashevsky was accused in formalism and his school was forgotten. But now, as N. D. Tamarchenko notes, "the series of books by Tomashevsky enter into the active fund of modern literary criticism" [8]. His "Poetics" helps us to open the content of form of such deep lyric composition as the crown of Guy Sabitov's sonnets “Шунды но жужа но..." (In English translation, "Sun sets - sun rises"). In particular, to make an amendment in author's reasoning about it. "I want to say the few words about the crown of sonnets" - he writes in introduction to this book "Joy". - I tried to fix in it the image of young talented poet, my unforgettable friend Michael Pokchy-Petrov, to talk about his short but bright life" [9]. The author of poem obviously succeeded in psychological drawing of the image of young talented poet, tragically death in his very blossom. As to "talk" about his short but bright life, it can be accepted only conventionally. The lyric character of the crown of sonnets based not on construction of fable line of the described person life activity but on formulation and development of lyric hero's feeling does not favor it. "The fable motives are seldom in lyric poetry, - B. V. Tomashevsky writes - the more often are the statistic motive deployed in emotional lines. Whereas poem talks about the some action, step of hero the motive of this action is not interlaced in causal-temporal chain and is devoid of the fable tension that needs the fable solution.- Scientist give also the next analogy" [10].

The poem is dialogical. Lyric hero permanently appeal to the picture of died friend, talented poet and theater actor Michael Pokchy-Petrov, which bright memory it is dedicated to, reminding the several facts of his life activity to declare his joy, hope, anxiety, sorrow about one or another event. These feelings form the content of composition. So, the subject of speech (lyric hero who is in fact equal to the author of biography) became the subject of description. As B. V. Tomashevsky writes, in process of lyric deployment often takes place "The conscious mixture of object and subject. Poet talks about external phenomena as about his internal feelings, mixing up his internal impressions with external images" [10]. It was said exactly as about Gay 
Sabytovs crown of sonnets. For example in eight sonnet, reminding days of being in Moscow with M. Pokchy-Petrov when they were students, author writes: "Быдэс страна-мынам вордскем доре, / Москва, Москва - мынам яратонэ!/Мед котькытчы вуттоз улонсюрес - / Уг кушты мон, дуно шаер, тонэ!” [4], ("My country, you is all within me - my native world! / Moskow, Moskow - my holy! / My native stars upwards/ I am not in sorrow..." [9]. In this words we can hear the voice of G. Sabytov's own feelings and aftersounds of the M. Pokchy-Petrov lyric consciousness expressed especially in his famous poem "Дор" ("Motherland"), and in the text this notion successively expands from the images of mother, native village, region, Udmurtia to the Moscow and the whole USSR.

Lyric hero (of the author of composition) is described as the true friend, citizen-patriot of our Motherland, poet-philosopher able to raise the personal facts of biography of described personage to the generalizing heights placing in focus of attention not so much the real details but its emotional value. "Тон дуннее льктон зоро сизьыл / Шундыё май, дыр, вал анаедль:: / Тульсс сямен, вож вожектиз узьым, / Кырзан жинграз чебер Вало дурын” [4], (“yоu was born in the fall / In your honor for the mother's sake/the winter crops were green in leas/ the songs was splattering above the Vala river" [9]. This is the beginning of the sequence of most important events of M. Pokchy-Petrov life activity that are in fact presented in enumerating form and the content is intensified not by the details of past but by the emotional attitude of author. At the same time there is underlined the mutual revelations of the author and hero, especially when they were in Moscow: «Ом ватылэ сюлэм малпанъёсмес, / Сюлэм осъёс вал волак усьтэмын. / Син пиштэмъя валам мылкылдёсмес - / Кезьыт я пось туннэ тынылд, мынылм?» [4], (“We did not hide the feelings from each other, / divided daily bread between us, / And knew by eyes without explications,/ About sun or snow in our hearts" [9].

The major order of the lyric plot gradually changes to the dramatic and then to the tragic one. «Тон жог жутскид улон тубат кузя, / Шумопоттыса гажась ас эшъёстэ. / Жингра кырзан тынад кылъёсылъя, / Кальк льљзе кылбур-малпанъёстэ» [4], (“you swiftly went on hill by your own way / You worked and blossom like the garden, / Your poems sounds just like waves, / And songs on poems jingled like ryes" [9], - it is the beginning of the last sonnet, and it is finished with the following lines: “Огнад дыръя гинэ сюлмыл вузэ - / Оло, шодскод сюресэдлэсь пумзэ” [4] (“Вит уои just hide the pain in bosom, / as if you feels the end of blossom" [9].

So, the tonality of feeling changes at lyric deployment. But neither dramatic, nor tragic effect beats down the main idea direction of the plot but on the contrary intensifies it by overcoming the negative situations.

Analyzing the internal structure of form and content relations in lyric texts B. V. Tomashevsky comes to the conclusion: "There is the typically three-parted construction of lyric poems, where theme is given in the first part, it develops by the side motives or is canceled by contradiction in the second part, the third one gives the emotional conclusion in the form of maxim or comparison $<\ldots>$.. [10].

The first motive or theme, as B. V. Tomashevsky puts it, sounds in the very beginning lines of the G. Sabytov's crown of sonnets: «Сиез-данэз овол ни сонетлэн, / Оз пыры со удмурт поэзие. / Туэ, шуо, крезез кылбурчилэн / Мед золтэмын луоз мукет сиен» [4], ("No formеr respect to the sonnet, /His star was frozen by sunset, / All say: it's time for songs and poems, / In gusli find new music's land" [9]. But in the very first sonnet this motive, in words of Tomashevsky, is "pushed” by contradiction: «Кьлзиськытээ сыче индылонлэсь, / Мон турттисько тани та вуж кабе / Тэрытыны аслам сюлэмылэсь / Косэмъёссэ, чик ватытэк, кабен» [4], ("Reminding the another's claim, / I don't want to follow, / I want to put in older frame, / Heat of my heart, dictate and sorrow" [9]). This contradiction (disobedience by the common opinion) in result finds its intensive development in thoughts and feelings of lyric hero and finishes in the last sentence addressed to the image of M. Pokchy-Petrov: «Весяк дырлы басьтиз ке но кулон, / Оз люкы асьмеды бугрес улон!» [4], (Despite the death that crossed the way, / we stay together till this day!" [9]). Its essence is in affirmation of eternity, immortality of good actions, good deals, kind, talented people. 
The theme of life eternity and good deals goes through all the composition from the tittle, this important component of its form - composition. According to researchers, title as the part of form of composition "is in fact the author's interpretation of the text" [11]. The meaning of the title of the crown of sonnets "Шунды но жужа но..." (“Sun sets - run rises") is connected with the common understanding of the eternal life circle presented especially in the Udmurt folk song of the same name and is deployed already in the initial thinking of the lyric hero about the preceding generations of people who created the base for M. Pokchy-Petrov creative actions. Until in the eight sonnets he personally "meets" the image of described personage and begins to empathize with its joy and sorrow. «Кыче со шуд - ma дуннеыл улон! Льктим - асьмельл дась нянь, юрт, диськут, - is just said in the second sonnet. - Выжылосмы юн тыршиллям толон - / Лэсьтиськон тир туннэ кызьы уд кут!» [4], ("What happiness - to live in world,/The parents made this world for us, / We must to say the kindly words, / It's time to show them how we trust" [9]).

The crown of sonnets perfectly fitted for Guy Sabytov's expression of the good memory about his friend. Because the structure of this genre is full of obligatory numerous repetitions that fasten the form and content of composition. The sonnets "remember" each other, the main one collects the main lines of it all.

«Весяк дырль басьтиз ке но кулон, / Оз люкы асьмеды бугрес улон!» (“Despite the death that crossed the way, / we stay together till this day!" - we also want to repeat this final sentence of the composition. Guy Sabytov created by his crown of sonnets the immortal verbal monument not only for Michael Pokchy-Petrov but also for himself. As painter would say, he created the "double portrait". The first of them was represented by the separate facts of Pokchy-Petrov's biography in the soffit light of lyric hero's feelings, the second one was described by the lyric deployment that is the flow of author's empathies with his friend-poet.

We could finish the article by this major tonality. But we obligatory must remember the final lines of the penultimate sonnet from this crown. «Кертти венок. Оз буйга нош сюлэм. / Сиез-данэз овол ни сонетлэн» [4], ("I made the crown but did not calm my soul / there is not respect to sonnet in this world") Poet-philosopher G. S. Sabytov was substituted here by the human Guy Sabytovich Sabytov, the close friend of Pokchy-Petrov, he probably hoped that creating the crown of sonnets he calms his heart. But the feeling of loss turned up unbearable for human!

\section{Conclusions}

N. A. Atnabaeva made the first but very serious step in study of generation and development of sonnet creation in Udmurt poetry. But her beginning needs continuation. In Udmurt literary criticism there are many theoretically skilled researchers. We want to believe that they will study this problem. Moreover in the plans of philological sector of URI of RAS for the next three years is set the aim of creation of collective thesis on the questions of theoretical history of Udmurt poetry. We want to hope that teachers-methodists will be interested in the article and use it for enrichment of the methods of literary education, especially in the sphere of lyric composition poetics.

\section{References}

[1] Jusufov, R. F. (1996). G. E. Vereshhagyn na kul’turologycheskoj karte Rossyy. Yzhevsk: Prosvetytel'. Udmurtskaja pravda, 10 oktabria.

[2] Jusufov, R. F. (2005). Ystoryja lyteraturyy v kul'turofylosofskom osveshhenyy. Moscow, 345-383.

[3] Vanjushev, V. M. (1983). Svoeobrazye razvytyja udmurtskoj poemyy. Svoeobrazye razvytyja udmurtskoj lyteraturyy y fol'klora. Yzhevsk, 74-96.

[4] Sabytov, G. S. (1975). Shundyy no zhuzha no... (Sonet'esles' venok). Myhayl Pokchy-Petrovez bure vajyysa. Jaratys'ko. Kyylbur'es no kyyrzan'es. Yzhevsk, 18-32.

[5] Vanjushev, V. M. (2008). Y vot sonetu vnov' pryshel pochet... Hudozhestvennaja slovesnost' fynno-ugorskyh narodov: ot ystokov k sovremennosty. Joshkar-Ola, 29-35. 
[6] Atnabaeva, N. A. (2004). Zhanr poemyy v udmurtskoj poezyy. Yzhevsk, 191.

[7] Atnabaeva, N. A. (2015). Venky sonetov - posvjashhenyja v udmurtskoj y blyzkorodstvennyyh komy y mordovskoj lyteraturah. Fylologycheskye nauky. Tambov. Voprosyy teoryy y praktyky, 1 (2), 26-29.

[8] Tamarchenko, N. D. (2002). «Poetyka» B. V. Tomashevskogo y ee sud'ba: B. V. Tomashevskyj. Poetyka. Moscow, 5-21.

[9] Sabytov, G. S. (1973). Solnce zahodyt - solnce vstaet. Venok sonetov. Svetloj pamjaty druga, poeta Myhayla Pokchy-Petrova. Radost'. Venok sonetov, Styhy. Pesny. Yzhevsk, 5-16.

[10] Tomashevsky, B. V. (2002). Poetyka. Moscow, 334.

[11] Vykulova, V. S. (2015). Konceptual'no-poetycheskyj smyysl ynterteksta «Pykovoj damyy» A. S. Pushkyna v odnoymennom rasskaze L. E. Ulyckoj. Tambov Vestnyk Tambovskogo unyversyteta: Gumanytarnyye nauky, 4 (144), 148-153. 